\title{
Análisis de la realidad textual en Niebla (1914) de Miguel de Unamuno.
}

\section{Analysis of Textual Reality in Mist (1914) of Miguel de Unamuno.}

DOI: $10.32870 /$ sincronia.axxv.n80.14b21

\author{
Jesús Miguel Delgado Del Águila \\ Universidad Nacional Mayor de San Marcos (PERÚ) \\ CE: tarmangani2088@outlook.com / ORCID: 0000-0002-2633-8101
}

Esta obra está bajo una Licencia Creative Commons Atribución-NoComercial 4.0 Internacional

Recibido: 08/03/2021

Revisado: $13 / 05 / 2021$

Aprobado: $14 / 06 / 2021$

\section{RESUMEN}

onsiderando el contexto bélico y el surgimiento de las vanguardias a inicios del siglo XX, fundamento en este trabajo las razones por las cuales la presencia del concepto de nivola, atribuida por Miguel de Unamuno para hacer referencia a la técnica literaria que emplea en su novela Niebla (1914), suscita una confrontación posible entre universos compuestos por elementos de la realidad y lo virtual. En ese sentido, será propicio explicar el procedimiento que origina esa colisión de planos establecidos. Para ello, recurriré a categorías literarias que sustentan las teorías de la ficción, según la percepción de Thomas Pavel y Marie-Laure Ryan.

Palabras claves: Análisis textual. Generación del 98. Mundo posible. Realidad textual. Taxonomía.

\section{ABSTRACT}

Considering the war context and the emergence of the avant-garde in the early twentieth century, I base on this work the reasons why the presence of the concept of nivola, attributed by Miguel de Unamuno to refer to the literary technique used in his novel Mist (1914), provokes a possible confrontation between universes composed of elements of 
reality and the virtual. In that sense, it will be appropriate to explain the procedure that originates that collision of established plans. For this, I will resort to literary categories that support the theories of fiction, according to the perception of Thomas Pavel and MarieLaure Ryan.

Keywords: Textual analysis. Generation of '98. Possible world. Textual reality. Taxonomy.

\section{Introducción}

Para este artículo literario, realizaré un análisis superficial de las estructuras formales y narratológicas que presenta Niebla de Miguel de Unamuno. Para ello, confrontaré la edición de Oveja Negra, publicada en 1985 en Colombia, para extrapolar el método de contrastación de categorías generales, que permitirá la corroboración de las propuestas epistemológicas con su respectiva interpretación.

La primera sección de este trabajo sustentará panorámicamente el entorno que contextualiza esta otra literaria. Para comprobarlo, desarrollaré los referentes totémicos de la historia coetánea, que abarcan la situación europea en función de los cambios socioculturales producidos por las continuas guerras. Luego, se cotejará con la generación del 98, grupo literario al que subyació el escritor español, con la intención de reformular los estatutos de la novela. Como tercer punto, se argüirán las transformaciones sociopolíticas por las que ha transitado el autor para expresar su cosmovisión en su libro. En el cuarto, colocaré detalles biográficos y bibliográficos, con la consideración de su obra. Como último segmento, se hallará la definición de nivola, los aspectos destacables de Niebla y el argumento textual. Con estos cinco criterios, se esquematizarán los enunciados de la exégesis literaria, sin la finalidad de colegir fundamentos innovadores, sino para replantearlos.

La segunda parte de este estudio se orientará al análisis estructural de Niebla. El propósito es postular que esta cuenta con los atributos de un mundo posible y una realidad virtual. Para ello, se constatará con la clasificación elaborada por los teóricos Marie-Laure Ryan y Thomas Pavel, quienes se ciñen a la estructura narrativa con lo ficcional. Con ello, se aplicará la epistemología ya 
mencionada en la novela de Unamuno. Será imprescindible hacer una división en tres segmentos. El primer apartado se enfocará en el mundo posible, que se abordará desde las concepciones de Pavel y otros autores que prevalecen esa idea. Después, se explicará la relación mimética, la característica de la incompletitud, la veracidad del mundo posible, los campos de referencia, la existencia de los objetos del mundo real textual y su tipología: nativos y sustitutivos. Una vez expuestas estas categorías, será notable su articulación con los principales móviles que interactúan en esta, como Augusto Pérez, Eugenia Domingo del Arco y Miguel de Unamuno. Se pondrán fragmentos del texto que revelen su complexión como construcción ontológica y su participación en la novela como actantes funcionales. En el segundo segmento, se retomará la extrapolación de accesibilidad del mundo real al mundo real textual con las identidades de propiedades e inventario y la compatibilidad de inventario, junto con la cronología, la física, la taxonomía, la lógica, la analítica y la lingüística. Para ello, se insertará el típico ejemplo del diálogo que se establece en la entrevista del protagonista con el autor (Augusto-Unamuno). Para finalizar, se tratarán la inmersión y la interactividad en la realidad textual, que se asemejarán con el texto narrativo y se dilucidará cada categoría fluctuada por Marie-Laure Ryan. Con frecuencia, se recurrirá a la cita textual para confrontar con la argumentación afín.

\section{Abordaje panorámico de Niebla (1914)}

En esta sección, me cercioraré del entorno que se corrobora con la génesis del libro de Miguel de Unamuno. Para ello, desarrollaré el contexto histórico mundial, la generación del 98, los pensamientos filosófico y político, el autor y el significado de nivola, la novela en su ipseidad y el tópico de la emancipación. Una vez finiquitada la estratificación, fundamentaré el análisis de los autores teóricos.

\section{Contexto histórico mundial}

Para Erich Auerbach (1996), es medular el conocimiento de la historia para iniciar un estudio sobre un objeto literario. Luego, la interpretación será factible, ya que se considera el factor histórico 
como paradigma. En esta oportunidad, implica la documentación de los sucesos de Francia entre los años de 1910-1930, que se vincula con lo acontecido en Latinoamérica y Occidente, caracterizado por conflictos de las potencias europeas.

Entre 1910, surgen la Revolución mexicana, los proyectos bélicos de los países del primer mundo y la Primera Guerra Mundial (en 1914), que involucró a muchas nacionalidades. Recuérdese que Europa pasaba por una crisis que se exteriorizaba desde las vanguardias y las limitaciones que propalaba el sistema capitalista, como la calidad de vida y los nuevos valores. Muchos artistas y socialistas participaron como protesta ante ese periodo. Se cuestionó el sacrificio de los combatientes y la pretensión de alcanzar una posición destacable si ganaba la revolución socialista en Rusia. Austria perdió reconocimiento después de este atentado. Rusia fue exterminada con su base monárquica. Ante ello, eclosionó un sistema innovador de Gobierno, el bolchevique, a cargo de Lenin. Estados Unidos y Japón fueron potencias mundiales. Alemania dejó su imperio colonial, aunque mantuvo su infraestructura local. En cambio, en Francia, no suscitó así, al igual que en Gran Bretaña. Adicionalmente, su prestigio fue erradicado y, paulatinamente, su condición resultó equivalente a la de Norteamérica. El piloto alemán Manfred von Richthofen fue instintivo en esta confrontación.

Entre 1920, tras concluir la Primera Guerra Mundial, se instituyó la Sociedad de Naciones, que empezó con el interés de evitar cualquier tipo de vicisitud bélica. Rusia se convierte en la URSS y adopta la ideología marxista-leninista. Con ello, se evidenció la sumisión que tuvo al proletariado. Durante la guerra, Argentina, que propició negociaciones mercantiles con Europa, obtuvo una gran riqueza a nivel mundial. Alemania, que se limitó a los criterios del Tratado de Versalles. Esa decisión produjo una crisis notoria en ese lapso; paralelamente, se anheló la estabilidad económica e igualitaria con la República de Weimar, al mando de Paul von Hindenburg. Francia no atravesó por una situación idónea. Esto conllevó la falta de aceptación de la sociedad; es decir, inconsistencia política. Japón intervino con más frecuencia en su continente: administró Corea, se adscribió a sectores chinos y se apropió de colonias alemanas del Pacífico. Entretanto, Norteamérica continuó con intermitencias su desarrollo económico, a causa de la Gran Depresión de 1929. Con este 
acontecimiento, vuelve el periodo de crisis y la génesis de sistemas totalitarios (fascismo y nazismo) que generarán la Segunda Guerra Mundial. Culturalmente, es una época en la que imperan transmutaciones, avances científico y tecnológico (aparecen el automóvil, el avión, el cinematógrafo, el gramófono, etc.). Su valor totémico es la pretensión de modernización e innovación.

\section{La generación del 98}

Esta agrupación se confinó de las tradiciones precedentes, con el propósito de buscar una solución colindante y auténtica; en rigor, se trató de una asociación de eliminación y conflicto.

A pesar de los múltiples cambios políticos y sociales que afectaron a España durante la primera mitad del siglo XX, la eclosión cultural constató el replanteamiento de la sociedad: la creación es primordial y se propaga. Los especialistas atribuyeron la designación a este lapso como "La edad de plata", que inicia en 1898 y concluye con la Guerra Civil en 1936.

La primera alteración surge con la derelicción de las últimas colonias y su extenso periodo de declive, que se originó en el siglo XVII. Una congregación de escritores se rebeló ante esos hechos, a expensas de los motivos y las resoluciones para reconstruir lo que distinguió al país europeo. Se la denomina la generación del 98. En esta, se encuentran muchos exponentes enjundiosos de la Literatura española, quienes abordaron temas artísticos, científicos e históricos, que eran transferidos en ensayos, como su preocupación por Europa y los problemas que acaecieron. Algunos lograron una posición inminente y universal, como fue el caso de Miguel de Unamuno.

Cinco son las particularidades constantes en esta agrupación. La primera se estriba en el pesimismo patriótico; es decir, se asumía el nacionalismo como una ocasión para ostentar con amplificación. Esta debería impactar por sus componentes estéticos y algo olvidados. La segunda característica es la europeización, debido a que la cultura española pierde su rasgo tradicional y se deja influenciar por modelos extranjeros (como alemanes, ingleses y franceses). La tercera pauta se enfoca en el autodidactismo, ya que los escritores de esa generación son autodidactas. Transmiten sus ideas y sus doctrinas a la prensa y los libros. La cuarta eventualidad se basa en la emancipación, 
porque sus integrantes requieren un noble deseo renovador. Por último, predomina un estilo en los representantes de esta congregación, pues se perfeccionan concienzudamente con el lenguaje y se aprovechan del origen etimológico de las palabras. Poseyeron una actitud crítica e interrogativa y un deseo de modernizar y liberalizar al país europeo.

\section{Filosofía y política}

En este escritor europeo, se halla una negación ante cualquier tipo de sistema ya establecido. Por eso, la formación intelectual del autor se rige mediante el racionalismo y el positivismo, tópicos que la misma situación sociopolítica de España le exige (redacta artículos a favor del socialismo y su inquietud por su país). Adolf von Harnack provocó el rechazo de Unamuno por el racionalismo. Esto se observa en su obra San Manuel Bueno, mártir (1931), donde se encuentra con frecuencia la colisión entre la fe y la razón. El novelista es considerado uno de los predecesores de la escuela existencialista que, tiempo después, retoma importancia en el pensamiento de Occidente. Posteriormente, durante la guerra y a partir de agosto de 1936, Unamuno comenzó a recabar ideas para un libro que no terminaría de concretar. En este, plasmó su testamento político: El resentimiento trágico de la vida. Notas sobre la revolución y la guerra civil españolas.

\section{Miguel de Unamuno (Bilbao, 1864 - Salamanca, 1936)}

Su característica principal como escritor de lengua castellana no es la profusión de descripciones, los escenarios en los que transcurren sus historias o la narración perfecta, ni mucho menos su aporte está en sus personajes. La vida de ellos está organizada y planificada con perfección según su criterio. Cada uno conlleva una predeterminación en sus acciones que él mismo conoce y reconoce, pero que no significa que el lector sepa su desenlace, y aunque así ocurriera, es tan original, que no por ello la trama es incompleta. Otra peculiaridad del autor es que nada es producto del azar. Para ello, se valdrá de técnicas autónomas, que configuran la denominación de la nivola.

Cronológicamente, la obra narrativa de Miguel de Unamuno es la siguiente. Paz en la guerra (1895) es un libro en el que incorpora el contexto de la tercera guerra carlista (que supo en su 
niñez) para plantear la relación del yo con el mundo, supeditado al precepto de la muerte. En Amor y pedagogía (1902), concatena lo cómico y lo trágico en una reducción a lo absurdo de la sociología positivista. Recuerdos de niñez y mocedad (1908) es su biografía, enfocada en lo acaecido en Bilbao. El espejo de la muerte (1913) es un libro de cuentos. Niebla (1914) fue un texto esencial para el autor, que se diferencia por la inclusión del paradigma de nivola, que desbrida la narración de su supuesta forma estática. En Abel Sánchez, (1917), invierte el tópico bíblico de Caín y Abel, para presentar la complexión de la envidia. Tulio Montalbán (1920) es una novela corta sobre el problema íntimo de la derrota de la personalidad verdadera por la imagen pública del mismo hombre. También, en 1920, publica Tres novelas ejemplares y un prólogo. Su última narración extensa es La tía Tula (1921), en la que vuelve a plasmar el deseo de maternidad, ya apreciado en Amor y pedagogía y Dos madres. Además, se encuentra Teresa (1924), un cuadro narrativo que contiene rimas de Gustavo Adolfo Bécquer. En esta, se logra la exteriorización de la imagen de la mujer amada, junto con su recreación. Luego, con Cómo se hace una novela (1927), se revela la poética de las novelas del autor español. Para acabar, Unamuno escribe sus últimas novelas: Don Sandalio, jugador de ajedrez (1930) y San Manuel Bueno, mártir (1931), que se refiere a un sacerdote que predica algo en lo que él no consigue creer.

\section{Nivola, Niebla y emancipación textual}

Miguel de Unamuno reconoció la novedad que implicó su texto, ya que no acaece nada fundamental, sino que se trata de lo que le ocurrió al personaje, su accionar y su identidad. Por cierto, el escritor español declara que su libro no es más que una "nivola", un género que, en la obra es descrita por Víctor, y que, consistiría en una novela de acción rápida, de mucho dialogo y enfocada en lo que les suceda a los personajes. Su lectura es amena, entretenida y filosófica; por eso, didáctica y reconfortante. Asimismo, esta fue la primera narración en la que un protagonista se rebeló contra su autor por la decisión del creador de matarlo. 
Niebla es emblemática para Miguel de Unamuno, porque corresponde con el periodo literario que se denomina existencialismo, y constituye una de las obras inminentes de la generación del 98.

El ambiente que se articuló fue el de la sociedad española en la etapa finisecular del siglo XIX e inicios del XX, con su formalidad. En ese contexto, se exponen las clases sociales con distinción: la servidumbre y los amos. Por ende, se adjudica que todo debe ser perfecto para la clase magnánima, que era representada por Augusto. Entonces, se exhiben las incógnitas, el luto y la devoción a su figura en torno a lo que le acontece, junto con la dependencia de sus actos.

En la novela, el protagonista simula la nihilidad de la existencia humana, tal como Unamuno la siente. Apasionado por Eugenia, por compromiso personal, quiere contraer matrimonio con la muchacha. Al ser rechazado, querrá pagar la hipoteca de la casa que sus progenitores le dejaron. Esto será en vano. Augusto Pérez vive de rentas y le es fácil pagar la hipoteca sin transacción alguna. Pero Eugenia, enamorada del bohemio Mauricio, lo evita hasta que su amante le sugiere una relación esporádica. En consecuencia, ella se apropia de Augusto en detrimento de Rosario, y se casan. Sin embargo, la mujer regresa con Mauricio. Se aparta del protagonista que viaja a Salamanca para entrevistarse con el autor, de quien ha leído un ensayo sobre el suicidio. El escritor pretende recapacitarlo, para que asuma que no existe como persona real, sino que es un ente literario carente de vida individual e iniciativa para ejercer ese desenlace macabro. La última escena entre ambos es trágica: el personaje emancipador y Unamuno en su intento de imponer lo más inexorable de la ficción literaria (lo anulará en el momento que le convenga).

En Niebla, discrepan los intereses medulares del autor. El más exhaustivo es el rechazo vital a una muerte que significa el término de la existencia, la vida personal, al igual que la ruptura con un patrón determinado de novela procedente de la época del realismo.

\section{Análisis estructural de Niebla (1914)}

Luego de que se han pormenorizado elementos del primer capítulo, como el contexto histórico mundial que se desarrolla en Niebla, el aporte de las influencias de la generación del 98, los ideales 
filosóficos, políticos y literarios de Miguel de Unamuno, realizaré un análisis más detallado de esta novela. Para ello, he dividido por segmentos que aplican las teorías narratológicas en función de esta obra. De esta manera, se comprenderá la inclusión de la nivola desde su modo de construcción textual.

En el primer segmento, se explicará en qué consiste la definición de mundo posible, con su articulación en los principales móviles que interactúan en este, como Augusto Pérez, Eugenia Domingo del Arco y Miguel de Unamuno. Se pondrán ejemplos textuales que revelen su identidad y su participación en el libro como actantes funcionales.

Más adelante, se cerciorarán cómo los mundos presentados en Niebla parten del acceso del "mundo real" al "mundo real textual". Para ello, se añadirá el ejemplo del diálogo que se establece en la entrevista del protagonista con el autor (Augusto-Unamuno). Ahora, para hacer factible y veraz este recurso, es recomendable que estos planteamientos cumplan con los nueve requisitos teóricos que argumenta Marie-Laure Ryan, que se abarcarán posteriormente. Estos son la identidad de propiedades e inventario, su compatibilidad, las correspondencias cronológica, física, taxonómica, lógica, analítica y lingüística. En algunos casos, se confrontarán con fragmentos de la obra, en los que se aprecie directamente las características mencionadas.

Como último punto, se extrapolará la teoría de Marie-Laure Ryan con respecto a la inmersión y la interactividad en la realidad virtual. Para ello, prevalecen tres subtemas que convalidarán este postulado de la inmersión: el espacial, el temporal y el emocional. Esta tríada se complementará con la respuesta, el argumento o el personaje. En cada ocasión, se recurrirá convenientemente a citas textuales.

\section{Mundos posibles}

Estos se configuran desde una relación mimética con la realidad del mundo real. Roland Barthes (Pavel, 1995, p. 13) retoma esta idea como un aspecto contingente de los relatos. Esto permite que la ficción se derive de la realidad. En términos de Pavel, esta es la base del universo (compuesto por mundos alternativos) sobre su mundo actual concomitante. Del mismo modo, lo señala Aristóteles 
al ratificar que la mímesis es la esencia de la ficción. A partir de ese instante, el arte es considerado como una representación, notable en tres experiencias medulares que se producen por naturaleza: el juego, la fiesta y el símbolo. De estos talantes, Gadamer (Beuchot \& Arena-Dolz, 2006, p. 97) precisa que se trata de exposiciones repetitivas y entendidas en su sentido, pues cada sujeto impone sus leyes y sus costumbres para expresarlas en la sociedad. Con ello, se propone su peculiar organización interna, al igual que su propia desorganización. Este tipo de exposición imaginaria no solo se observa en su composición exógena y endógena; en rigor, se refiere al uso del lenguaje (actos de habla) o el discurso, como lo comprende Thomas Pavel y Wolfgang Iser.

Una de las características del mundo de ficción es la incompletitud (Pavel, 1995, p. 130), que es provocada por la heterogeneidad semántica de la actividad textual. Mientras que los mundos reales son completos y estables, la estructura de los mundos ficticios es ambivalente: indeterminado e inconsistente. Por más que el autor procure ser pormenorizado en las descripciones históricas, políticas, sociales o estéticas, no podrá erigir un mundo que sea totalmente accesible como lo es el real. Miguel de Unamuno pretende describir el panorama estético de lugares específicos de España en Niebla, como el interior o el exterior de una habitación, tal como se nota en el siguiente fragmento:

Era una casa dulce y tibia. La luz entraba por entre las blancas flores bordadas en los visillos. Las butacas abrían, con intimidad de abuelos hechos niños por los años, sus brazos. Allí estaba siempre el cenicero con la ceniza del último puro que apuró su padre. Y allí, en la pared, el retrato de ambos, del padre y de la madre, la viuda ya, hecho el día mismo en que se casaron. Él, que era alto, sentado, con una pierna cruzada sobre la otra, enseñando la lengüeta de la bota, y ella, que era bajita, de pie a su lado y apoyando la mano, una mano fina que no parecía hecha para agarrar, sino para posarse como paloma, en el hombro de su marido (Unamuno, 1985, p. 36).

La ficción se extrae gradualmente de la verdad al seguir un proceso histórico del mundo real. Esto permite que sea ilimitado y variable con respecto al estado de cosas posibles. Entonces, los mundos ficcionales son accesibles desde el mundo real por canales semióticos, ya que el proceso de 
información es asumido como mediador. Desde allí, se emplea el término elaborado por Garrido y Harshaw sobre el "campo de referencia interno" (Garrido, 1997, p. 127), que trata del universo del texto o toda una red de nexos interrelacionados de diversos tipos: personajes, diálogos, situaciones, etc. Por otro lado, se encuentra el "campo de referencia externo", que son todos los que se configuran fuera del libro, como la temporalidad y el espacio (en el caso de Niebla, se alude a una topografía ubicada en España durante el siglo XX).

La existencia de un objeto se deriva de la correspondencia de una serie de propiedades, que se consolida desde una percepción retrospectiva (como cuando se utiliza la analepsis, que consiste en un relato precedente, secundario a la narración y que sirve como un tipo de evocación) hacia los hechos, mediante la semántica y la semiótica. Acerca de ello, Gérard Genette (1998) señala lo siguiente: "La caracterización, evidentemente, es la técnica de construcción del personaje a través del texto narrativo" (p. 94). En ese sentido, hasta los nombres propios serán fundamentales, porque se muestran como abreviaturas de conjuntos o combinaciones de descripciones definidas. Verbigracia, al acotar al personaje Miguel de Unamuno, se refiere directamente al autor real de Niebla. Este no deja de tener un rol totémico en la novela, puesto que decidirá el destino del protagonista, por su historia fracasada entre el posible romance con Eugenia. Ahora, para pormenorizar las funciones de los personajes, efectuaré una clasificación pertinente.

Primero, Augusto Pérez es el protagonista de Niebla, un hombre de edad promedio y buena familia socioeconómica, como también una óptima educación, solitario, impuntual, fumador de habanos, que se dedicaba a la meditación y la formulación de teorías filosóficas para sí. Su vida pacífica le permite esos momentos de ocio y reflexión. En el texto, actúa acuciosamente sobre las inquietudes que le acontecen, pese a estar enamorado. Por ejemplo, al apreciar a Eugenia por primera vez, se ilusiona y decide estar junto a ella. Simultáneamente, su ingenuidad y su ignorancia de la vida determinan que sus decisiones sean fortuitas y poco convincentes.

Segundo, Eugenia Domingo del Arco es una joven emprendedora que imparte clases de piano, aunque no le guste la música. En una primera instancia, ella se considera un modelo ético femenino; luego, demostrará lo contrario. Posee un rasgo dominante y no se deja influenciar. 
Físicamente, es atractiva y arrogante. Su cosmovisión se supedita a ser independiente, surgir por sí misma y tener control de su vida. Esto se explica por la ominosa situación que vivió cuando era niña (el suicido de su padre) y por el deseo de superación de los problemas económicos.

Tercero, el escritor español aparecerá en su propia obra. Aparte de que se narra su historia de vida, es entrevistado por Augusto y decide su muerte. Su presencia es enigmática, sin dejar de ser omnisciente.

Walter Mignolo (1986, p. 70) y Terence Parsons (Pavel, 1995, pp. 42-43) aluden a un tipo de objeto que se introduce en un texto, el objeto nativo, que es inventado por el autor del relato, como los personajes que intervienen para el desarrollo de la historia: Augusto Pérez, Miguel de Unamuno, Eugenia, don Antonio, Liduvina, Rosario, etc., al igual que los sucesos de un espacio peculiar. A continuación, añado un fragmento inicial de la novela, en el que es notable el monólogo del protagonista, quien irá erigiendo racionalmente la composición interna y externa de Eugenia. Entretanto, al hacer esta construcción ontológica, se evidencia cómo este personaje revela sus roles y su caracterización concomitante:

“He aquí un chisme utilísimo - se dijo-; de otro modo, tendría que apuntar con lápiz el nombre de esa señorita y podría borrarse. ¿Se borrará su imagen de mi memoria? Pero ¿cómo es? ¿Cómo es la dulce Eugenia? Sólo me acuerdo de unos ojos... Tengo la sensación del toque de unos ojos... Mientras yo divagaba líricamente, unos ojos tiraban dulcemente de mi corazón. ¡Veamos! Eugenia Domingo, sí, Domingo, del Arco. ¿Domingo? No me acostumbro a eso de que se llame Domingo... No; he de hacerle cambiar el apellido y que se llame Dominga. Pero, y nuestros hijos varones, ¿̇habrán de llevar por segundo apellido el de Dominga? Y como han de suprimir el mío, este impertinente Pérez, dejándolo en una $\mathrm{P}$, ¿se ha de llamar nuestro primogénito Augusto $\mathrm{P}$ Dominga? Pero... ciadónde me llevas, loca fantasía?". Y apuntó en su cartera: Eugenia Domingo del Arco, Avenida de la Alameda, 58 (Unamuno, 1985, pp. 23-24). 


\section{La accesibilidad del mundo real al mundo real textual}

Marie-Laure Ryan establece unas relaciones de accesibilidad del mundo real, implicadas en la consolidación del "mundo real textual" (Garrido, 1997, pp. 183-185). Estas se clasifican de nueve modos.

Primero, se corrobora con la identidad de propiedades, que se estriba en la argumentación de que el mundo real textual es accesible desde el mundo real si los objetos comunes en ambos mundos comparten los mismos componentes. En la novela de Miguel de Unamuno, los regímenes políticos, sociales y económicos se valen de una misma percepción, ya que se refieren a acontecimientos remotos que están registrados en el siglo XX. De estos, resulta enjundiosa la ambigüedad en la forma de abordar los aspectos religiosos (se atentaba contra los principios éticos y devotos de algunos creyentes).

Segundo, se menciona la identidad de inventario, que consiste en la correspondencia de la composición equitativa entre objetos. En Niebla, se muestra una pluralidad de prototipos humanos, los cuales, a pesar de plasmar alguna ambigüedad física o moral, son justificados en tal sentido que no se pierde la coherencia del relato, ya sea por medio de diálogos o narraciones que se exhiben inconsecuentes en el libro. Se patentiza una visión retrospectiva (analepsis), para aludir y completar una historia que no está dilucidada al inicio.

Tercero, se encuentra la compatibilidad de inventario, que reanuda el cumplimiento de la inclusión en el mundo real textual de los elementos del mundo real y los patrones nativos. Esta se expone con mayor precisión al fundamentar la importancia y la vigencia de los lugares que son puestos en escena, así como la iglesia o las residencias de Augusto y Eugenia, porque el autor trata de persuadir al lector, desde un trabajo de redacción. Describirá y mostrará rasgos estéticos e históricos, como también exteriorizará atribuciones semántica y semiótica que remitirán a la valoración que ejercen estos topos sobre la sociedad $y$, en especial, los personajes que se desenvuelven de una manera más libre que otros (en rigor, el protagonista en función de Eugenia y Unamuno). 
Cuarto, se hace referencia a la compatibilidad cronológica, que persiste ante la ausencia de controversias al momento de distinguir entre los tiempos presente, pasado y futuro. En Niebla, se aprecia la recurrencia a la linealidad temporal: los acontecimientos narrados se cuentan secuencialmente. Por ocasiones, prevalecen pausas que sirven para relatar un pensamiento o una descripción, como cuando se sabe la desdicha del protagonista, quien no deja de proyectarse en torno a cómo morirá. A partir de ese instante, se produce una prolepsis: una narración de hechos futuros posibles.

Quinto, otro talante que abarca Marie-Laure Ryan es la compatibilidad física, que es factible si las leyes naturales son las mismas. En el libro, se cuestiona esta peculiaridad con la relación del autor-personaje. Esto genera extrañamiento, debido a que el mundo real textual pretende asimilarse o confrontar con el universo de la realidad. Verbigracia, Unamuno y Augusto subyacen a dos universos heteróclitos, aunque han sido conectados mediante un espacio y un tiempo desprovisto, planteados con ironía por la novela.

Sexto, se halla la compatibilidad taxonómica, que se origina al ser notoria la correspondencia entre los mundos sobre las propiedades de las mismas especies emergidas. En ese caso, sí existe esa correlación con el ser humano, física y espiritualmente, pero se indaga en el texto acerca de su pertenencia en otro mundo donde el autor está inmerso como personaje antes de cotejar con la realidad concomitante.

Séptimo, se articula la compatibilidad lógica cuando se presenta la aceptación de los fundamentos de no contradicción y medio excluido. En Niebla, lo que se polemiza es la desconexión ética que padece Eugenia al someterse al romance. Esto suscitará que su construcción utópica como mujer se transgreda y sea factible para catalogarla como antagónica por el personaje principal.

Octavo, la compatibilidad analítica es propicia cuando el mundo real textual y el mundo real comparten con similitud las verdades metódicas, basadas en que los objetos designados cuenten con los mismos componentes esenciales. Esto es asequible en esta obra literaria, a excepción del pasaje en el que se establece un diálogo con el autor en el capítulo XXXIII: 
Cuando recibí el telegrama comunicándome la muerte del pobre Augusto, y supe luego las circunstancias todas de ella, me quedé pensando en si hice o no bien en decirle lo que le dije la tarde aquella en que vino a visitarme y consultar conmigo su propósito de suicidarse. $Y$ hasta me arrepentí de haberle matado. Llegué a pensar que tenía él razón y que debí haberle dejado salirse con la suya, suicidándose. Y se me ocurrió si le resucitaría.

"Sí - me dije-, voy a resucitarle y que haga luego lo que se le antoje, que se suicide si es así su capricho".

Y con esta idea de resucitarle me quedé dormido. A poco de haberme dormido se me apareció Augusto en sueños. Estaba blanco, con la blancura de una nube, y sus contornos iluminados como por un sol poniente. Me miró fijamente y me dijo:

-iAquí estoy otra vez!

-¿A qué vienes? -le dije.

-A despedirme de usted, don Miguel, a despedirme de usted hasta la eternidad y a mandarle, así, a mandarle, no a rogarle, a mandarle que escriba usted la nivola de mis aventuras...

- iEstá ya escrita!

- Lo sé, todo está escrito. Y vengo también a decirle que eso que usted ha pensado de resucitarme para que luego me quite yo a mí mismo la vida es un disparate, más aún, es una imposibilidad...

- ¿̇Imposibilidad? -le dije yo; por supuesto, todo esto en sueños.

-iSí, una imposibilidad! Aquella tarde en que nos vimos y hablamos en el despacho de usted, ¿̇recuerda?, estando usted despierto y no como ahora, dormido y soñando, le dije a usted que nosotros, los entes de ficción, según usted, tenemos nuestra lógica y que no sirve que quien nos finge pretenda hacer de nosotros lo que le dé la gana, ¿recuerda?

-Sí que lo recuerdo.

- Y ahora de seguro que, aunque tan español, no tendrá usted real gana de nada, ¿verdad, don Miguel?

-No, no siento gana de nada. 
-No, el que duerme y sueña no tiene reales ganas de nada. $Y$ usted y sus compatriotas duermen y sueñan, y sueñan que tienen ganas, pero no las tienen de veras.

-Da gracias a que estoy durmiendo -le dije-, que si no...

-Es igual. Y respecto a eso de resucitarme he de decirle que no le es hacedero, que no lo puede aunque lo quiera o aunque sueñe que lo quiere... (Unamuno, 1985, pp. 146-147).

Para finiquitar, el último componente que elabora Marie-Laure Ryan es la compatibilidad lingüística, que resulta factible si es comprensible el lenguaje. En el mundo planteado por Miguel de Unamuno, los personajes interactúan con el mismo idioma; por ende, no existe forma de constituir una conexión con un extranjero o un sujeto que tenga la función de traductor.

\section{La inmersión y la interactividad en la realidad virtual}

Marie-Laure Ryan (2004, p. 18) menciona que la realidad virtual es una experiencia interactiva e inmersiva, en la que existe una filiación con lo imaginario, que se va exponiendo a través de imágenes, sin importar que sea por ilusiones. También, lo virtual favorece los procesos de eclosión, ya que propone nuevas expectativas, así se develen con falsificación o simulación. Estas imágenes son mutables. Se originan de objetos abstractos del pensamiento, como el espacio, el tiempo, la memoria y la acción. Se ciñe a la realidad, es decir, a lo intransigente y lo intratable, a comparación de lo real, como es notorio en el desarrollo de Niebla. A continuación, añado un segmento en el que se aprecia de qué modo el protagonista se resiste a ser introducido al mundo de los muertos. Esa negación permitirá que se establezca un desbalance sobre la organización consolidada por la novela, en la que solo el escritor español tiene autoría. En ese sentido, muestro el fragmento del diálogo que suscita entre Augusto y Miguel de Unamuno en el capítulo XXXI:

—Pero ipor Dios!... - exclamó Augusto, ya suplicante y de miedo tembloroso y pálido.

-No hay Dios que valga. iTe morirás!

—Es que yo quiero vivir, don Miguel, quiero vivir, quiero vivir...

- ¿No pensabas matarte? 
-iOh, si es por eso, yo le juro, señor de Unamuno, que no me mataré, que no me quitaré esta vida que Dios o usted me han dado; se lo juro... Ahora que usted quiere matarme quiero yo vivir, vivir, vivir...

-iVaya una vida! -exclamé.

-Sí, la que sea. Quiero vivir, aunque vuelva a ser burlado, aunque otra Eugenia y otro Mauricio me desgarren el corazón. Quiero vivir, vivir, vivir...

-No puede ser ya... no puede ser...

-Quiero vivir, vivir... y ser yo, yo, yo...

-Pero si tú no eres sino lo que yo quiera...

-iQuiero ser yo, ser yo!, iquiero vivir! -y le lloraba la voz.

-No puede ser... no puede ser...

-Mire usted, don Miguel, por sus hijos, por su mujer, por lo que más quiera...

Mire que usted no será usted... que se morirá.

Cayó a mis pies de hinojos, suplicante y exclamando:

-iDon Miguel, por Dios, quiero vivir, quiero ser yo!

-iNo puede ser, pobre Augusto - le dije cogiéndole una mano y levantándole-, no puede ser! Lo tengo ya escrito y es irrevocable; no puedes vivir más. No sé qué hacer ya de ti. Dios, cuando no sabe qué hacer de nosotros, nos mata. Y no se me olvida que pasó por tu mente la idea de matarme...

-Pero si yo, don Miguel...

-No importa; sé lo que me digo. Y me temo que, en efecto, si no te mato pronto acabes por matarme tú.

-Pero ¿no quedamos en que...?

-No puede ser, Augusto, no puede ser. Ha llegado tu hora. Está ya escrito y no puedo volverme atrás. Te morirás. Para lo que ha de valerte ya la vida...

-Pero... por Dios...

-No hay pero ni Dios que valgan. iVete! (Unamuno, 1985, p. 139). 
La realidad virtual funciona cuando se logra la inmersión y la interactividad. La primera significa estar en el mundo textual de manera imaginativa. En ese sentido, mientras más transparencia del medio exista, mejor será la inmersión. Esta se requerirá (Ryan, 2004, p. 213). Esto conlleva que el libro se asimile como un mundo ("como si"). En Niebla, prevalece el cuidado con la descripción topológica. Esto permite que la introducción del lector sea dinámica a través de los pormenorizados recursos estéticos e históricos. Entonces, existe un acceso del mundo actual al posible, donde, a la vez, se aprecian tres modos de implicación que propone Marie-Laure Ryan (2004, p. 152) para una narración. Primero, está la inmersión espacial, que se constituye desde una localización. En rigor, para la novela, es un pueblo de España y su entorno, ya que allí es donde sucede la mayoría de los hechos, además de que se toma como referencia para otros lares. Segundo, se patentiza la inmersión temporal, con la que se ubica la narración en un tiempo determinado. En este caso, se alude a la historia desarrollada en el transcurso del siglo XX, que comparte el mundo real del autor (quien ha vivenciado y expuesto ese lapso en su narración). Tercero, está presente la inmersión emocional. Mediante ella, la subjetividad es indispensable para que las historias oscilen. El escritor europeo utiliza varios rasgos de la generación del 98, como la emancipación ante el pesimismo patriótico, desde la innovación de formas literarias que complejizan el nivel de lectura tradicional y los tópicos antiéticos que son examinados como una reacción ante la moral mal fundada (como la infidelidad, el adulterio, el sadismo o el masoquismo).

La interactividad considera el libro como un elemento dinámico: un juego. Para ello, es inexorable poseer un grado de dinamismo, al igual que conocer el lenguaje que se emplea en la lectura. Al respecto, Marie-Laure Ryan señala lo siguiente: “En sentido figurativo, la interactividad describe la colaboración entre el lector y el texto en la producción de significado" $(2004$, p. 34). En la novela corroborada, se observa la interactividad, desde el léxico complejo y erudito. Asimismo, la construcción interna de la historia adquiere un rubro privilegiado. Recurre con mesura a los juegos temporales, como la analepsis en su preferencia para detallar la remembranza del protagonista o la mujer afrontada; la prolepsis, sobre todo en Augusto para proyectar su trágico destino sin salvación; también, las pausas para hacer descripciones o monólogos orientados a un referente. Se requieren 
mentiras por los personajes, como se aprecia en la etapa de indecisiones que atraviesa Eugenia por hallar el sentido del amor desde el sexo. El encubrimiento de historias se irá revelando paulatinamente hasta saber la verdad de los hechos y los personajes, ya sea por la historia proferida, sus costumbres o sus funciones, tal como se exterioriza en el siguiente fragmento del capítulo $\mathrm{V}$, en el que se cuenta la vida de los padres del protagonista:

De su padre apenas se acordaba; era una sombra mítica que se le perdía en lo más lejano; era una nube sangrienta de ocaso. Sangrienta, porque siendo aún pequeñito lo vio bañado en sangre, de un vómito, y cadavérico. Y repercutía en su corazón, a tan larga distancia, aquel ihijo! de su madre, que desgarró la casa; aquel ihijo! Que no se sabía si dirigido al padre moribundo o a él, a Augusto, empedernido de incomprensión ante el misterio de la muerte.

Poco después su madre, temblorosa de congoja, le apechugaba a su seno, y con una letanía de ihijo mío! ihijo mío! ihijo mío! le bautizaba en lágrimas de fuego. Y él lloró también, apretándose a su madre, y sin atreverse a volver la cara ni apartarla de la dulce oscuridad de aquel regazo palpitante, por miedo a encontrarse con los ojos devoradores del coco.

Y así pasaron días de llanto y de negrura, hasta que las lágrimas fueron yéndose hacia dentro y la casa fue derritiendo los negrores (Unamuno, 1985, pp. 35-36).

Un elemento postremo que permite la interactividad en el libro es lo que utiliza el autor al querer mostrar las acciones injustas que se cometen en la historia textual, ya sea por el infortunio de los personajes, el mal uso de la religión, la ética o la sociedad. Como tales, adoptan su momento de reivindicación: Augusto no muere en la novela. En otros casos, se degenerarán, como acontece con Eugenia y sus pasiones prohibidas. De esa forma, el lector interactúa con la obra literaria, ya que va configurando un juicio que discrimina las estratagemas que discrepan con las leyes moral y textual. 


\section{Conclusiones}

Primero, los sentimientos son incontrolables. Conducen a situaciones impensables, como la muerte o actuar sin equilibrio. Se toma como referencia la causa de la rebelión del personaje ante el autor: su desatino amoroso. Este fue el motivo totémico para la desarticulación del mundo textual tradicional (regido por los principios de los universos reales textuales).

Segundo, el tiempo se va registrando por indicadores, sin que tenga la menor transcendencia. Con el espacio, sucede lo mismo. Se sabe que la acción se desarrolla en una ciudad de provincias, pero no cuál es. Esto se explica de la siguiente manera: Unamuno no pretende que el lector se enfoque en el contexto, sino en la trama. Es insoslayable recordar en qué consistía una nivola, un nuevo género, en la que el espacio-tiempo se eximía de la norma de estilo. Este libro se exoneró de sus paradigmas clásicos, sin ser valorizado por sus exégetas. En ese sentido, destaca en las producciones de Unamuno. Fue un correlato material emancipador del autor, que incitó a la concientización y la libertad de los escritores coetáneos.

Tercero, esta obra literaria se rige de todas las condiciones para ser definido como mundo posible, puesto que el mundo real textual asimila patrones reconocibles del mundo real. Los objetos nativos y los sustitutivos privilegian ese rasgo mimético, en cuanto personajes (Augusto, Eugenia y Unamuno) y lugares (referencias topográficas de España).

Cuarto, el mundo real textual es accesible al mundo real por ser compatible con las características planteadas por Marie-Laure Ryan: el inventario, la cronología, la física, la taxonomía, la lógica, la analítica, la lingüística y la identidad en sus propiedades y sus inventarios, de modo que las condiciones son pertinentes. De ello, se confirma que el mundo postulado por el autor es un mundo posible.

Para finiquitar, Niebla cumple con los talantes que configuran la realidad virtual, porque en esta suscitan la inmersión y la interactividad por el lector. A su vez, el narrador fluctúa con precaución la introducción de descripción de elementos estéticos, éticos y narrativos: la presencia de la analepsis, la prolepsis, las pausas y las elipsis es indispensable para que se busque el efecto intencionado: el de ir revelando paulatinamente la información veraz del discurso. 


\section{Referencias}

Auerbach, E. (1996). Mímesis. La representación de la realidad en la literatura occidental. México: Fondo de Cultura Económica.

Beuchot, M. \& Arena-Dolz, F. (Dirs.) (2006). 10 palabras clave de la hermenéutica filosófica. Navarra: Editorial Verbo Divino.

Garrido, A. (Comp.) (1997). Teorías de la ficción. Madrid: Arco Libros.

Genette, G. (1998). Nuevo discurso del relato. Madrid: Ediciones Cátedra.

Mignolo, W. (1986). Teoría del texto e interpretación de textos (1.a ed.). México: Universidad Nacional Autónoma de México.

Pavel, T. (1995). Mundos de ficción (1.a ed.). Caracas: Monte Ávila Editores.

Ryan, M. L. (2004). La narración como realidad virtual. La inmersión y la interactividad en la literatura y en los medios electrónicos. Barcelona: Paidós.

Unamuno, M. (1985). Niebla. Colombia: Oveja Negra. 